\title{
REVISITING SPORT AND TOURISM INTERRELATIONSHIPS: THE CASE OF CAMEROON
}

\author{
Siyabulela NYIKANA \\ University of Johannesburg, School of Tourism and Hospitality, \\ College of Business and Economics, South Africa, e-mail: siyabulelan@uj.ac.za \\ Tembi M. TICHAAWA* \\ University of Johannesburg, School of Tourism and Hospitality, \\ College of Business and Economics, South Africa, e-mail: tembit@uj.ac.za
}

\begin{abstract}
Citation: Nyikana, S. \& Tichaawa M. T. (2020). REVISITING SPORT AND TOURISM INTERRELATIONSHIPS: THE CASE OF CAMEROON. GeoJournal of Tourism and Geosites, 29(2), 756-771. https://doi.org/10.30892/gtg.29229-504
\end{abstract}

\begin{abstract}
This study seeks to examine the nature of sport and tourism interrelationships in Central Africa, using Cameroon as a case study area. Using a mixed-method research paradigm, the study assesses such linkages within a complex socio-political environment on the basis that such interrelationships have been studied from a developed world context where the socio-political environment is conducive to sport tourism development, unlike in the current study. Questionnaire surveys $(n=1186)$ were conducted with sport tourism event attendees in four major events in Cameroon, complemented by interviews with key resource personnel $(n=16)$ in the industry. The key findings indicate that the interrelationships between sport and tourism in this context are relatively weak, especially at the policy and planning levels, despite there being potential for strengthening of these at the local operational level for sustainable tourism development. Additionally, such interrelationships between sport and tourism present unique challenges that are informed by the developing world context of the study and thus require a rethink in planning and management.
\end{abstract}

Key words: Tourism, Sport tourism interrelationships, Tourism development, Sustainable tourism planning, Cameroon

\section{INTRODUCTION}

The interrelationship between sport and tourism has been explored by many scholars who have noted how the growth in the popularity of sport, as well as the notable development of global tourism, have resulted in the recognition of sport tourism as a relevant field of focus for governments and academics alike (see works by Getz, 2013; Hemmonsbey \& Tichaawa, 2018; 2019; Walker et al., 2013; Tichaawa et al., 2018; Nyikana \& Tichaawa, 2018b; 2018c). Such a growth, mainly attributed to the bidding for, and hosting of sport tourism events, has been as a result of the more perceptible and

\footnotetext{
* Corresponding author
} 
synergetic relationship between sport and tourism generally (Kennelly \& Toohey, 2014; Fourie \& Santana-Gallego, 2011). This relationship has led to an increased academic focus on the existing overlaps between the two, with a view to highlighting the notable growth of the niche area of sport tourism (Nyikana \& Tichaawa, 2018a; Nyikana, 2016; Getz, 2013; Fourie \& Santana-Gallego, 2011). According to research conducted by Weed and Bull (2004), whilst the sport tourism niche has been topical in both academic and political spheres, most research on the phenomenon has stressed how, historically, the two domains have only been looked at as simply an overlap, and not necessarily mutually beneficial and interlinked disciplines. Resultantly, Kennelly and Toohey (2014) argue that the result has been that academic analysis of sport tourism has lacked comprehensiveness and has tended to be geographically skewed towards the resourceful Global North.

This is, in spite of the fact that there has been a notable increase in the number of developing countries who actively and aggressively participate in sport tourism through the regular hosting of sport tourism events (Hemmonsbey \& Tichaawa, 2019; Nyikana \& Tichaawa, 2018c; Nyikana, 2016; Gibson et al., 2012; Swart \& Bob, 2007). The main goal of such hosting is linked to the perceived associated tourism benefits especially in areas such as infrastructure improvement, branding and socio-economic restructuring of rural and urban destinations (Higham \& Hinch, 2002; Honari et al., 2010; Hemmonsbey \& Tichaawa, 2018; Ilies et al., 2018a,b; Marcu et al., 2020). Despite this increased engagement, we argue in this paper that there remain major challenges for sport tourism development in the developing context. In terms of research, what has largely been lacking has been an investigation of the interrelationship between the two disciplines, given the different socio-economic, environmental and political dynamics that manifest themselves relative to the Global North. In addition the situation in the African geography is even more complex, with some destinations known to be more resourceful than others. Ciampicacigli and Maresca (2004) argue that the main challenge with developing nations is that they have not up to this point made sport tourism development one of their points of focus for destination planning.

As an example, Kennelly and Toohey (2014) point out how the agencies and ministries responsible for sport and tourism respectively have often not recognised the importance of collaborating, especially in relation to policy, planning and the implementation of said policies. Consequently, Weed and Bull (2004) opine that development endeavours fail, despite shared interests between the two areas. Specifically, for Tichaawa, Bob and Swart (2018) the lack of planning and the limited purposeful effort put into consolidating the interlinkages between tourism and sport, to accrue mutual benefits, is still largely lacking in the developing, and particularly African context. Moreover et al. (2010) have affirmed that while in the cases where there has been purposeful collaboration, which has yielded relatively positive returns, in cases where this has not been carefully considered and managed, conflicts have been the result.

Oftentimes in the context of developing countries, very little purposive effort is put into consolidating the interlinkages for mutual benefits between the tourism and sport industries (Gozner et al., 2017; Ilies et al., 2018c; Kennelly \& Toohey, 2014; Nyikana \& Tichaawa, 2018c; Tichaawa et al., 2018). In the few cases where there has been planned cooperation, it has often been short-term in nature, with differing objectives which, in turn, skews the long-term possibilities for local economic development in the respective destinations (Kennelly \& Toohey, 2014; Acha-Anyi, 2018). Sport tourism events in particular draw attention in this regard, because they are often seen as shortcuts to achieving long-term benefits from both sport and tourism respectively (Bob \& Swart, 2010; Lincu et al., 2018). This article seeks to understand the interrelationship between sport and tourism in a developing world context, using Cameroon as a case study area. 
The study considers the gains made in the area concerning sport and tourism while highlighting the areas that should be of focus if a vibrant sport tourism niche sector is to be realised. The first section of the article provides a literature review which focuses on an overview of sport tourism, highlighting the specific linkages that can be forged between the two domains. The review also focuses on the importance of the economic and sociopolitical environments required in ensuring growth and development in the sport tourism sphere. Later, the materials and methods used in the study are discussed, and the findings therefrom explained. The article ends off with the conclusions that are drawn from the study, as well as the ensuing recommendations going forward.

\section{LITERATURE REVIEW}

Sport tourism has been used to extend the sport concept into more of a leisure holiday activity, and in this way developing complementary services and products for visitors to destinations (Ciampicacigli \& Maresca, 2004). The concept of sport tourism and the hosting of sporting events, in particular, has gained attention as a potential tool for urban and rural development and regeneration (Radicchi, 2013; Nyikana \& Tichaawa, 2018a; 2018c). Sport tourism, especially events are known to provide host destinations with several tangible and intangible benefits which otherwise would have taken a longer period to be achieved (Hemmonsbey \& Tichaawa, 2019; Tichaawa et al., 2018; Knott \& Hemmonsbey, 2015; Nyikana, 2016; Nyikana et al., 2014; Smith, 2012; Tichaawa \& Swart, 2010). These scholars argue that the successful planning, hosting and management of these events, irrespective of their magnitude, brings about benefits such as the high-profile promotion of existing offerings and opportunities on a global scale; development of world-class sporting facilities; infrastructure and superstructure upgrades; and for developing countries specifically, gaining a head-start for the bidding and hosting of other future events, amongst other benefits.

Besides the benefits mentioned above for sport tourism events hosting, other key considerations include the critical lessons which could be learnt by the stakeholders towards the further development of local sport tourism and in the overall expansion of sport tourism markets, with the aim of accommodating other types of sports and reaching wider audiences (Nyikana, 2016; Bama \& Tichaawa, 2015; Getz, 2013; Smith, 2012; Tichaawa \& Swart, 2010). According to Smith (2010), these events could also lead to investment stimulus as well as assisting in gaining civic engagement and ensuring that the progress made by the hosting government structures is broadcast to the wider public. In developing countries, the focus tends to be on smaller-scale events due to their perceived ability to expedite development of infrastructure, and their ability to bring about unique tourism gains, while maintaining a vibrant but yet sustainable sport tourism sector (Nyikana \& Tichaawa, 2018a; Gibson et al., 2012). Moreover, the popular appeal of sport tourism, coupled with the mentioned benefits to hosting destinations, and the large-scale related commercial sponsorship associated with it, remains a significant niche area in the global context (Bob \& Swart, 2010).

In any case, the parallel expansion of sport and tourism has resulted in the two disciplines being a focal point of research by academics, and broadly being development options for world governments (Tichaawa et al., 2015; Gammon \& Robinson, 2003; Nyikana \& Tichaawa, 2018c). For its part, sport has become a global affair which attracts large sums of money, a great deal of media attention, political interest in its development and management, as well as large numbers of participants and a global audience alike (Nyikana et al., 2014). On the other hand, tourism has remained one of the world's premier industries, growing at rapid rates, while also generating large amounts of revenue on an annual basis (Sharma \& Bisht, 2019; Hemmonsbey \& 
Tichaawa, 2019; Acha-Anyi, 2018; Hermann \& du Plessis, 2016; Bama \& Tichaawa, 2015; Gibson et al., 2012; Nyikana et al., 2014; Rogerson, 2013). Against such developments, the argument for sport and tourism interrelationships and the collaboration between the two emerges (Nyikana \& Tichaawa, 2018c). In the earlier works, Standeven and de Knop (1999), and later Kurtzman and Zauhar (2003) advocated for this integration and the need to recognise that there exists a symbiotic relationship between the two disciplines, arguing that tourism aids sport in the form of increased numbers at sporting events, while sport also helps further tourism through offering a wider variety of visitor experiences, to enhance the overall tourism experience. Thus, Kurtzman and Zauhar (2003) noted that this evident growth in sport tourism, and the specific points of convergence for sport and tourism have, in recent times, become more perceptible and as such, open up numerous possibilities for the explicit identification of the common areas in order to effectively plan for them and the general sport tourism development agenda, a view closely shared by Hinch and Higham (2003).

Whilst there is general consensus that the points of convergence between sport and tourism have become more visible in recent times (Hinch \& Higham, 2003; Kennelly \& Toohey, 2014; Swart \& Bob, 2007; Weed \& Bull, 2004; Kurtzman \& Zauhar, 2003; Nyikana \& Tichaawa, 2018c), Weed (2003) argued that these had not been explicitly defined due to the fact that globally, the structures responsible for sport or tourism development tended to be established, developed and operated wholly separate from each other, and as a result of this, any interlink or collaboration tends to be irregular in its nature, a situation which is common in the developing world context. Some studies point out that, even in the few instances where there has been collaborations formed, they have either been of a short-term nature and for a limited time for exploitation of an obvious opportunity, or the coordination thereof has been disappointing and lacking end-product. Other studies (see Kennelly \& Toohey, 2014; Nyikana \& Tichaawa, 2018c; Weed \& Bull, 2004; Weed, 2003) point to one of the possible reasons for this failure as the attitude of stakeholders from both disciplines. In this respect, they argue that sport organisations have tended to have a fear that in collaborating with the tourism counterparts, they may be limited in terms of direct gains from the existing tourism benefits linked to sporting events as an example. Swart and Bob (2007) suggested that there be a quantification process of the specific linkages between the two phenomena, in an effort to negate this concern, which would subsequently provide critical evidence of the extent of the linkage involved in the collaboration. Such an exercise would also assist to identify the weaknesses and strengths within the existing interrelationships between the two, making it possible to further strengthen these accordingly as the situation requires.

According to Weed and Bull (2004), in possessing similar interests and target audiences, sport and tourism agencies should collaborate in producing and distributing informative material for tourists and sport participants alike, an exercise which should enhance the relations between them. Besides, the sport and tourism activities tend to interact in the same natural and built resources that are shared by tourists, participants and residents alike, and therefore linking them in terms of the development initiatives and potentially making additional sources of funding more accessible than they might have been individually (Swart \& Bob, 2007; Weed \& Bull, 2004). However, Swart and Bob (2007) caution that, for this linkage to be effective, careful attention should be paid to the social, economic and environmental concerns that are generally associated with sport and tourism development. In the context of the current study, and on the back of the limited international tourism arrivals in Cameroon, the emphasis tends to be skewed towards the economics exclusively, with little attention to social and environmental concerns (Tichaawa et al., 2018; Harilal et al., 2019). 
In summarising the main challenges associated with poor linkages of sport and tourism within the African continent, Swart and Bob (2007) posit that firstly poor communication and coordination efforts between sport and tourism play a key role. Secondly, they argue that the poor execution of leveraging each other's channels into the appropriate target markets is another challenge. Thirdly, a lack of input from smaller event committees, especially in the tourism sphere is a key impediment. The fourth challenge is linked with a lack of access to fan bases by the tourism industry resulting in uncertainty about the most fitting channels to disseminate tourism information for sport tourists. Lastly, the poor alignment of calendars to best capitalise on balancing periods of low activity in either industry is seen as another key obstacle. Therefore, in this study, we argue that sport and tourism in the Cameroonian context exists within a unique setting, which is largely unconducive to the effective development of the sport tourism sector. In this way, we posit that the stakeholders in the two industries are directed by set rules imposed by way of the national development plan, and because of other global issues. Sport and tourism should be integrated using astute government policy, sound strategic planning, and the development of facilities and services based on the overlapping nature of the two, especially in the context of Cameroon, and similar Sub-Saharan Africa economies.

In attempting to develop African economies, Nunkoo (2012) suggests that national governments should involve themselves through the creation and management of institutions, department and ministries, as well as policies that guide tourism generally, and in this case sport tourism development for environmental, political and economic reasons and outcomes. In sport tourism, the difficulty is that sport federations often set the institutional and political frameworks in pursuit of the goals and design of projects linked to sport tourism events (Cornelissen, 2011). In response to garner more political support from the citizens, governments often attempt to strike a balance between economic priorities, the environment and the local communities (Mosedale, 2015; Nunkoo \& Smith, 2013). This is on the basis that governments have started to see sport as part of a broader programme of community development, beyond the actual sport itself.

In the African context, much scrutiny is placed on the governments for their inability to effectively deal with socio-economic challenges like unemployment, crime, illiteracy and poverty amongst other social ills (Tichaawa, 2017; Kimbu \& Tichaawa, 2018), which hinder citizens' trust in their governance (Nunkoo \& Smith, 2013; Tichaawa \& Idahosa, 2020). Other challenges include the high levels of corruption amongst public officials, and the lack of equitable treatment of citizens and the protection of their rights regarding proposed developments (Nunkoo \& Smith, 2013). Nelson (2012) noted how nearly all African states, except South Africa, Botswana and Namibia, fell in the bottom half of the Transparency International's annual Corruption Perceptions Index regularly. The disappointing levels of infrastructure to support sport tourism, declining economies, and political climates that are not conducive to development have not helped the situation on the continent (Lamberti et al., 2011; Ngoka \& Umeakuka, 2013). This is a situation that is not helped by the fact that there is frequent confusion on where government responsibility is, and where the institutional planning for sport tourism belong (Kimbu, 2012; Kimbu \& Ngoasong, 2013; Panagiotopoulos, 2015).

Whilst some countries in the Global North have a regulatory framework governing sport tourism activities, in Africa generally there is a lack of such institutional frameworks to support the development of sport tourism (Panagiotopoulos, 2015; Harilal et al., 2019) besides the reliance of Global North frameworks. It is against this basis that sport tourism in Africa should perhaps be developed more from a regional and local competition basis, that adopts a bottom-up and community-led approach, to ensure less formal development and management style 
that encourages decision-making and buy-in from those affected (Misener et al., 2013; Tichaawa et al., 2018). In their research, Misener et al. (2013) cite places that have successfully development sport tourism like North America and Europe as places that have typically ensured that governance is characterised by non-hierarchical, shared governance amongst communities and their service providers, especially at local economy levels, something not currently happening in this study's context. Nevertheless, once more, this goes back to the fact that effective community participation may not be achieved due to the inconduciveness of the socio-political conditions in the context. Effective participation of the community rests on the social, economic and political structures, which are directed by the clarity of direction from the national government regarding sport tourism policy, and this is not the case in many parts of Africa.

\section{MATERIALS AND METHODS}

This study adopted a mixed-method research design to collect data from selected stakeholders in the domain of sport and tourism in Cameroon. In-depth, face-to-face semi-structured interviews were held with the 16 stakeholders involved. Such stakeholders operate within different tiers of government and the private sector. Once an interview was completed, a snowball sampling approach was also used, wherein the interviewee was requested to recommend a contact who could provide the required information for the study. This technique was significantly useful for follow-up interviews and to ensure that the relevant stakeholder with information was included in the sample. Questionnaire surveys developed based on the literature review and documentary analysis on tourism in Cameroon were also used to target event attendees at four (4) prominent sport tourism events that were hosted between 2016 and 2018 as shown in Table 1 below. Given that the sample size of the respondents was not known, in intercepting the attendees, a spatially-based systematic sampling approach was employed on event days. In this way, the first respondent was approached randomly, and thereafter every tenth $\left(10^{\text {th }}\right)$ attendee was targeted. In total, $n=1186$ questionnaires were collected and deemed usable after the data collection period. The distribution of the questionnaires in relation to the chosen events is detailed in Table 1.

Table 1. Distribution of surveys $(\mathbf{n}=\mathbf{1 1 8 6})$

\begin{tabular}{|l|c|}
\hline \multicolumn{1}{|c|}{ Name of sport event } & Total number of questionnaires \\
\hline 2016 Women Africa Cup of Nations & 384 \\
\hline Mount Cameroon Race of Hope - 2017 & 202 \\
\hline MTN Elite One Premier League game - 2018 & 300 \\
\hline Central African University Games - 2017 & 300 \\
\hline TOTAL & $\mathbf{1 1 8 6}$ \\
\hline
\end{tabular}

The questionnaire surveys were self-administered and distributed according to the ratios shown in the table. Where self-administration was not possible, trained fieldworkers were on hand to assist with the completion of the questionnaires. Once the data collection period was finished, the surveys were quality checked, coded, and captured accordingly. Since the study sought to establish the association between sport and tourism in Cameroon, a Chi-square test of independence (Fischer's Exact test) was conducted. Practically, the statements about sport were tested for association with those about tourism in the same question. The question had options for respondents to choose from i.e. YES or NO. According to Bryman, Bell, Hirschohn, dos Santon, Du Toit, Masenge, Van Aardt and Wagner (2014), the Chi-square test is used to establish how confident the researcher can be that there exists a relationship or association 
between two nominal variables. Thus, the effect size was measured by the phi coefficient, a correlation coefficient that has values between 0 and 1. Based on Cohen's criteria, a value of less than 0,3 indicates a small effect size, one between 0,3 and 0,5 indicates a medium effect size, while one whose value is greater than 0,5 indicates a large effect size (Pallant, 2007; Field, 2009). For the contextualisation of such associations and interrelationships, excerpts from the interview transcripts were used in conjunction with the quantitative findings. This helped provide the necessary meanings to the relationships accordingly. Qualitative data was thematically analysed.

\section{RESULTS DISCUSSIONS}

\section{Summary of respondents' profiles and involvement in sport tourism}

In terms of the demographic profiles, an overwhelming majority of those surveyed at the sporting events were Cameroonians $(81.2 \%)$ as opposed to those from other countries (18.8\%). The international visitors included those who were mainly from countries such as Nigeria, Mali, South Africa and Zimbabwe from the African continent, and the United States of America (USA), China, Canada and Germany from the rest of the world, amongst others. In terms of gender representation, there was an almost split distribution with the majority of them (53\%) being men, while there were $47 \%$ women. This hardly comes as a surprise given that in recent times there has been a considerable growth in the number of women participating in sporting events, indicating that sport is no longer a male-dominated space (Jones, 2008; Tichaawa, 2013; Achu, 2019). Generally, the majority of the attendees were youthful given that a combined $86.2 \%$ of them were those between 18 and 40 years of age. On the other hand, the key informants that were interviewed were mainly (82\%) in the age category of between 41 and 50 years of age. The respondents were relatively well educated given that a combined majority had obtained a form of qualification ranging from a minimum of a diploma or certificate, right up to a postgraduate degree (60.9\%). This was backed up by the large number of those who were either full-time, parttime employees or self-employed (71.9\%) accordingly, see Table 2 below.

In the existing literature on sport tourists, involvement and participation are largely dominated by those who are enthusiastic devotees of sport, and who often engage in promotional activities such as watching TV, listening to radio commentary on sports, buying sports merchandise, and travelling to distant places to attend, and spectate sporting events (Smith \& Stewart, 2007; Nyikana \& Tichaawa, 2018b).

In this regard, it was not surprising to find that the majority of the respondents (67.9\%) were mainly involved in sport tourism as spectators. This number was followed by those who described themselves as volunteers (20\%), participants (18.7\%) and workers in the sporting event on offer (11.5\%), while only $7.3 \%$ indicated their involvement as being event organisers within the sport tourism event space. Nonetheless, the results show that there exists an opportunity to leverage sport tourism for the development of Cameroon's local areas because the spectators and participants were from many different parts of the country and beyond and as such, their commitment to the events presents a multitude of opportunities. Moreover, given the dominance of local Cameroon citizens at the events, there exists a solid platform from which domestic tourism could be tapped into by the relevant authorities in the country.

This is particularly important when considering that many of the attendees were from different provinces within the country, thereby implying that a strong willingness to travel cross-country for sport tourism attendance exists. The domestic tourism opportunities presented by sporting events in this context also link to the need for the promotion of a dynamic domestic tourism market that, up to this point outperforms the international tourism market in Cameroon anyway (Kimbu \& Ngoasong, 2013). 


\section{Sport tourism interrelationship examined \\ Sport helps to boost tourism in the local area - Tourism needs sport in order to increase visitor numbers to the local area}

Sport has been identified as an effective vehicle that could be used for the revival of tourism in local areas (Bouhaouala, 2015; Gibson et al., 2012; Odounga-Othy \& Swart, 2016). In particular, Gibson et al. (2012) have argued that in places where the economy, especially as relating to tourism's contribution to it, have been declining, sport has sometimes been considered as the tool required for injecting the developmental impetus. This is linked to the fact that sport attracts tourists to local areas that they otherwise would not have visited (Nyikana et al., 2014; Radicchi, 2013). The above two statements were tested for association, and the test indicated a significant association with a p value of $<0.000$ as shown in Table 2 further down.

However, the phi coefficient was 0.193 , thus indicating a small effect in terms of the association. This implies that the proportion of attendees who gave the same answer to both statements (either Yes/Yes or No/No) was significantly different from those who gave different answers (Yes/No). Ultimately, the findings show that there is an association between sport and tourism in the context of the two statements. The finding affirms what the existing literature suggests, that in many destinations, sports have constantly been used to boost visitor numbers to said destinations (Nyikana et al., 2014; Smith \& Stewart, 2007). However, the strength of this association remains small in terms of the effect. In Cameroon, the onus rests on those involved to increase the effect of this association to advance and fast-track tourism, and more importantly to boost visitor numbers on a domestic and international front (Nyikana \& Tichaawa, 2018c).

As highlighted in the key informant interviews, a major limitation in Cameroon is that the sport and tourism sectors typically compete for similar markets. However, they fail to capitalise on this fact especially by ensuring that they collectively work on promotion of both the sporting events and the tourist host destinations to the participants and attendees, as well as the tourists alike. This would ensure that they are able to increase the markets for both domains in the long-term, thereby strengthening the relationship between sport and tourism. In this regard, the interrelationship linked to branding, marketing and promotion is seen as being particularly weak in the context of the study, despite the acknowledgements made in relation to its potential.

\section{Sport helps to boost tourism in the local area - Tourism brings more people to sport events}

In the existing literature, some authors (Jones, 2008; Smith \& Stewart, 2007; Nyikana \& Tichaawa, 2018b) have suggested that some tourists travel to destinations for many other reasons, but once at the destination, tend to consider attending sport tourism events that are on offer. Thus, tourism plays a hand in increasing the numbers of visitors to sporting events. The test regarding this revealed a significant association between tourism bringing more people to sport events and sport helping to boost tourism in the local area with $\mathrm{p}<0.000$. The phi coefficient of 0.158 however indicated a small effect, thereby indicating that the proportion of respondents who gave the same answer to both statements (Yes/Yes or No/No) was significantly different from those who gave different answers to both statements (Yes/No). What is clear from this is that an association between sport and tourism exist in Cameroon. Moreover, there exists more opportunity regarding the overlapping development interests between the two that could be exploited going forward, provided that the strength of this association is enhanced. As argued by an official from the Ministry of Sport and Physical Education in Cameroon: 
Under normal circumstances, when there is a sport competition, especially an international football match or marathon, many people come. Even though they are coming for the match or race, on the days when they are not playing or watching they have to eat and go visit many places that are not the same as those from their country of origin. You see that this is how sport has helped tourism. In addition, in some way tourism helps sport because these happen on days when sport is not taking place.

The above statement shows that, there exists this interrelationship between sport and tourism in the context of Cameroon, even though the strength of it is relatively weak. This is probably linked to what Swart and Bob (2007) argued is the poor communication and coordination efforts between the two government departments and associated stakeholders, linked to the aligning of calendars for sport and tourism respectively. An official from a major sponsor of sport in Cameroon was also critical in this respect suggesting that this strategy was not being executed effectively in the country. He argued that other countries who were successful in sport tourism development enhanced the relations between sport and tourism innovatively; something he felt was not being explored in Cameroon:

In Cameroon, sport cannot contribute to the development of tourism effectively. In some countries, sport is a key asset to tourism development, but not here. We have not tapped into this, so what can we offer to the sport attendees when they come in terms of tourism offerings remains unknown to me.

In respect to the above, it is clear that there exists a major concern regarding the possibility of linking sport and tourism to achieve development initiatives such as urban development and regeneration. In particular, in the interviews attention was drawn to the fact that, theoretically speaking, sport and tourism are favourable vehicles through which urban development initiatives could be executed in Cameroon. However, these are often compromised by the tendency of officials to focus solely on the economics involved in this, neglecting the social and environmental responsibility pillars of development. Thus, the relationship is weak, and currently not being harnessed to its potential.

\section{Sport helps to boost tourism in the local area - Tourism can help raise the profile of weaker sporting events}

The test regarding the association between these statements provided interesting results. There was a significant association between tourism helping raise the profile of weaker sporting events and sport helping to boost tourism in the local area, as the test yielded a score of $\mathrm{p}<0.000$. Furthermore, the phi coefficient score was 0.331 , indicating a medium effect regarding the association. Once more, the findings confirm what has largely been documented in that tourism is seen as one of the contributors to the visitor numbers at sporting events, and in this instance, being seen as playing a role in growing the profile of the 'weaker' or smaller sporting events in terms of numbers and interest in them. Specifically in this case, the recent endeavours by Cameroon to host major sporting events, and the general rich sporting culture there, there exists a platform for authorities to leverage tourism for the further enhancement of sport, which may ultimately lead to a vibrant sport tourism industry. The challenge in this interrelationship as unpacked by the key informants was that the tourism stakeholders were excluded from the practical activities by their sport counterparts. They argued that they are not involved in any sporting event planning and organising, ranging from the small-scale events to the larger scale events. In this respect, they argued that more emphasis was on making the sport participants and visiting teams feel comfortable and ready for the event, failing to 
consider that they had a role to play on days when there was no sporting activity. As described by one official from the Ministry of Tourism and Leisure:

Sport plays an important part in tourism, the two are related. However, when it comes to specific application of this relationship, planning and organising sport events in Cameroon is very disconnected and not linked. The organisers of the events know that they should involve tourism people as a main partner but they do not do this. We have some very good ideas and knowledge of what could be done on non-event days, but we are not consulted.

From the above statement, it is clear that there exists a solid opportunity for sport and tourism interrelationships to be harnessed for the development of both disciplines. What appears to be an obstacle is the lack of trust and collaboration between the two especially as observed by those from the tourism domain, who feel excluded from sport tourism development despite their obvious expertise in the areas beyond the event spaces for the attendees and participants. Likewise, the stakeholders collectively argued that there needed to be more collaborations between the two domains. This collaboration though, they felt could only be enabled by the leaders of the ministries. In particular, they highlighted the need for the two ministries to work together in attempting to align their calendars such that they are able to assist each other, with sport filling in the 'off-peak' periods for tourism, and tourism aiding sport with entertainment opportunities and activities on non-event days. They felt that this would assist in enhancing the relationships between sport and tourism in Cameroon in the long-term.

Table 2. Sport helps to boost tourism in the local area $(n=1186)$

\begin{tabular}{|l|c|c|}
\hline \multicolumn{1}{|c|}{ Statement } & Fischer's Exact test P-value & Phi coefficient \\
\hline $\begin{array}{l}\text { Tourism needs sport in order to increase } \\
\text { visitor numbers to an area }\end{array}$ & 0.000 & 0.193 \\
\hline Tourism brings more people to sport events & 0.000 & 0.158 \\
\hline $\begin{array}{l}\text { Tourism can help raise the profile of weaker } \\
\text { sporting events }\end{array}$ & 0.000 & 0.331 \\
\hline
\end{tabular}

\section{Sport cannot prosper without the existence of tourists - Tourism needs sport in order to increase visitor numbers to an area}

The parallel growth trajectory that has been followed by sport and tourism has meant that the two often tend to coexist and frequently overlap in many areas of operation (Uvinha et al., 2018). Against such a context, the test was conducted between sport and tourism in relation to their (inter)dependence for local areas. When testing this relationship, the test revealed no significant association between the two statements with a score of $\mathrm{p}<0.092$, as shown in Table 3 below. The phi coefficient of 0.066 indicated a small effect in respect of the association, meaning there was no significant difference between those who gave the same answer to both statements, and those who gave different answers. In other words, the attendees did not necessarily make an association between sport and tourism in relation to these statements, probably on the basis that they felt that sport, generally could grow without necessarily getting the boost from tourism. Besides, sport is seen as a way of life in Africa in any case (Nyikana \& Tichaawa, 2018c). At the same, time, given how the two are often simply seen as an occasional overlap in contexts such as Cameroon, this does not come as a surprise. For example, in the key informant interviews, an official from the Ministry of Tourism and Leisure was quite dismissive about the likelihood of sport being integrated into their planning activities, especially as relating to tourism promotion of local areas: 
I do not grasp how sport can promote tourism in Cameroon. I really do not know how it can promote tourism because I do not work at the Ministry of Sport and Physical Education.

Such a response brings about concerns regarding the interrelationships that can be strengthened in the context of sport tourism development in Cameroon. The weak collaboration efforts amongst stakeholders and the lack of initiatives that are geared towards achieving this symbiotic working relationship therefore serves as a major limitation to the potential development of sport tourism there.

\section{Sport cannot prosper without the existence of tourists - Tourism brings more people to sport events}

The test between these two statements indicated a significant association with a score of $\mathrm{p}<0.000$. The phi coefficient value of 0.147 indicated a small effect regarding the association. As mentioned above, the respondents felt that while sport may be able to prosper without necessarily calling on tourism assistance, the existence of tourism in the destinations where sport events occur certainly plays a role in sport development because tourism brings more people/attendees to the events. Indeed, prior research studies that have been conducted (Taks et al., 2009; Nyikana et al., 2014) have shown that at times people who travel to a destination for tourism reasons, may in turn seek to participate, particularly through spectating, at existing sport tourism events that they find at the destination. Once more, this shows that, while there is a relatively weak linkage between sport and tourism, potential exists and is acknowledged by those on the ground. However, for this linkage to be exploited, strategic and purposeful planning should be considered for the leveraging of this. This is the recurring challenge as highlighted by the officials that were interviewed. In essence, the officials stress the need for more intensive collaborations across board in order to maximise on the opportunities that are present. As a representative of an NGO that deals with sport promotion argued:

There are many relationships that exist between sport and tourism, because you have to consider that there are many opportunities in the tourism sector in Cameroon that are yet to be explored, where sport could be used to help. The problem is that the government does not have the necessary capacity and time to do it on their own. It needs all of us, private business, sport people, tourism people and NGOs, so that we collectively work towards a good sport tourism sector here.

The interviewees felt that the need for collaboration could not be greater, given that this would likely increase the incentives for investments from both the public and private sectors in sport tourism in the country. A manager from MTN, a major sport sponsor suggested that there were many private organisations for example, which had the capacity to invest in sport and tourism. However, they were reluctant to do so because they do not have trust in government and harboured concerns about the lack of relationships that exist between the different ministries concerned with sport tourism development.

\section{Sport cannot prosper without the existence of tourists - Tourism can help raise the profile of weaker events}

When testing for the association between these two statements, no significant association $(\mathrm{p}<0.107)$ was found, with the phi coefficient also confirming a small effect (0.063) in this respect. This meant that those who gave the same answer to both statements (Yes/Yes or No/No) was not significantly different from those who gave different answers (Yes/No). Thus, whilst there is merit and acknowledgement of the fact that tourism may assist in raising the profile of weaker sporting events in Cameroon, there was no direct association between sport and tourism specifically regarding the two statements. 
Revisiting Sport and Tourism Interrelationships: The Case of Cameroon

Table 3. Sport cannot prosper without the existence of tourists $(n=1186)$

\begin{tabular}{|l|c|c|}
\hline \multicolumn{1}{|c|}{ Statement } & Fischer's Exact test P-value & Phi coefficient \\
\hline $\begin{array}{l}\text { Tourism needs sport in order to increase } \\
\text { visitor numbers to an area }\end{array}$ & 0.092 & 0.066 \\
\hline Touri sm brings more people to sport events & 0.000 & 0.147 \\
\hline $\begin{array}{l}\text { Tourism can help raise the profile of weaker } \\
\text { sporting events }\end{array}$ & 0.107 & 0.063 \\
\hline
\end{tabular}

Sport and tourism are two separate things that cannot be combined Tourism needs sport in order to increase visitor numbers to an area

As shown in Table 4 below, the test indicated a significant association between tourism needing sport in order to increase visitor numbers and sport and tourism being two separate things that cannot be combined $(\mathrm{p}<0.006)$. The phi coefficient value of 0.106 indicated a small effect in relation to this association. This meant that the proportion of attendees who gave the same answer to both statements (Yes/Yes or No/No) was significantly different from those who gave different answers to both statements (Yes/No) given. The findings imply that, while there is an association between the two statements, sport and tourism are currently seen as two separate things that cannot be combined. This is despite the acknowledgement that there is potential for their collaboration. What currently limits this collaboration is the current socio-political climate and setup which does not exhibit much cooperative collaboration between the ministries promoting sport and tourism respectively (Nyikana \& Tichaawa, 2018c), a situation that occurs in spite of the obvious gains that could be made in relation to sport increasing tourism arrivals in particular. An official from the Ministry of Tourism and Leisure summed this up saying:

Sport and tourism are not as related as they should be here. At our level in the local municipalities, we share ideas with our counterparts, but we all know that those will not go anywhere because those who influence are people who sit there in the capital city in high offices and plan for what is supposed to happen in the future, without considering the realities here on the ground. Therefore, in tourism we plan alone, those in sport plan alone, everything is centralised to the respective ministry.

In further explaining the above statement, the tourism official gave an example of the isolated nature of infrastructural development. He argued that sport and tourism often use the same infrastructure, and as such, if they bundled their planning together, attracting funding for such infrastructural investment would be easier and both domains' purposes would be better served.

\section{Sport and tourism are two separate things that cannot be combined - Tourism brings more people to sport events}

There was no significant association between tourism bringing more people to sport events and sport and tourism being two separate things that cannot be combined with $\mathrm{p}<0.672$. The phi coefficient of 0.019 indicates a small effect in this regard as well. This further shows the nuances of uncertainty shown above, regarding uncertainty between what is possible in relation to sport and tourism being interlinked, and the reality of what currently transpires in Cameroon. Once more, the blame for this uncertainty is directed towards the lack of collaboration and the encouragement of such collaborations from the national government plans. An official from the Ministry of Sport and Physical Education indicated that the linkage between sport and tourism especially as relating to the ability of tourism to bring more spectators to sport events was there for all to see during such events. However, there was a lack of acknowledgement and attempt to strengthen this relationship: 
I think sport and tourism should link. That is fundamental, because, despite the fact that, at higher levels, as government we tend to disassociate tourism and sports, the fact is sport is a big factor of tourism and vice versa. People travel for sporting competitions, but they also come to discover other aspects of the host destination.

Another key informant from the sport sponsorship expanded on this by suggesting that the disconnection between sport and tourism in this instance was also exacerbated by how little consultation generally happens in all forms of projects in the country. By this suggestion, he argued that investment in both tourism and hospitality tended to be haphazardly designed thus compromising the principles of sustainability generally:

The tourism and sport government officials have this coincidental way of planning and operating. Look at how they have constructed big stadiums, but beyond the stadium, the infrastructure is not connected to the stadium. The roads are bad, there is no signage, and it is bad. Developing the stadium is supposed to complement the area and improve roads and other infrastructure leading up to the stadium. This will bring more people.

\section{Sport and tourism are two separate things that cannot be combined - Tourism can help raise the profile of weaker sporting events}

The test between tourism being able to help raise the profile of weaker sporting events and sport and tourism being two separate things that cannot be combined, revealed no significant association between the two $(\mathrm{p}<0.631)$. In addition to this, the phi coefficient value of 0.022 indicated a small effect for this association, suggesting that, the proportion of respondents who gave the same answer to both statements was not significantly different from those who gave different answers.

Table 4. Sport and tourism are two separate things that cannot be combined ( $\mathrm{n}=1186)$

\begin{tabular}{|l|c|c|}
\hline \multicolumn{1}{|c|}{ Statement } & Fischer's Exact test P-value & Phi coefficient \\
\hline $\begin{array}{l}\text { Tourism needs sport in order to increase } \\
\text { visitor numbers to an area }\end{array}$ & 0.006 & 0.106 \\
\hline Tourism brings more people to sport events & 0.672 & 0.019 \\
\hline $\begin{array}{l}\text { Tourism can help raise the profile of weaker } \\
\text { sporting events }\end{array}$ & 0.631 & 0.034 \\
\hline
\end{tabular}

\section{CONCLUSION}

The main purpose of this study was to examine the interlinkages of sport and tourism in Central Africa using Cameroon as a case study area. Self-administered questionnaire surveys were carried out at four distinct sport tourism events in Cameroon, in an effort to establish these interrelationships between sport and tourism. These were complemented by interviews with key informant interviews with stakeholders in both the sporting and tourism sectors in Cameroon. By far and large, the findings reveal that there are a number of interlinkages between the two, especially in relation to the ability of each to enhance the other. For example, existing literature (Odounga-Othy \& Swart, 2016; Tichaawa, 2017; Hemmonsbey \& Tichaawa, 2019; Getz, 2013) reveals that tourism has often made a significant contribution towards boosting visitor numbers at sporting events, whilst on the other hand, sport has enhanced tourism by complementing existing tourism offerings at destinations. However, in this study it was found that the specific linkages were relatively weak, owing to a lack of purposeful and cogent planning in the part of the public sector. Of particular concern was that despite the perceptible gains to be made in the planning for, and management of sport tourism, there still remains a lack of policy and planned collaborations between the authorities involved for the two domains. Kennelly and Toohey (2014) stress the need for collaboration even in areas where sport and tourism are managed by different government departments, as this allows for mutual benefits and better coordinated strategies that exploit the long-term gains from the linkage. 
In Cameroon specifically, and many parts of Africa generally, sport and tourism tend to be managed wholly separate from each other, with minimal interactions between the two, despite the strong advocating for collaboration in existing literature. In this study, this is exacerbated by the centralised nature of operations, with a lot of the planning for sporting events being done at the highest level, with minimal or no input from those at the operational level, thereby confining the extent to which constructive feedback could be used in driving policies that make the most of the obvious linkages that currently exist between sport and tourism (Nyikana \& Tichaawa, 2018c). Tichaawa (2017) points out that this approach leads to a fragmented drive in relation to the initiatives that are in place for growing tourism and sport, because there is a lack of effective stakeholder participation process. Amongst the main areas identified that could be improved in this context are infrastructure, investment attraction, branding and marketing, urban regeneration as well as inter-governmental collaborations. These were areas that were found to be relatively weak in terms of relationships in Cameroon. The study therefore argues for a rethink in the way sport and tourism are managed in this context. For the effective promotion of a vibrant sport tourism sector that can revitalize the economy of Cameroon, a bottom-up approach to policy formulation should be implemented; wherein those that are at the operational levels of the sport and tourism overlap (such as the event managers, organisers, local communities where the events are hosted etc.) are given the opportunity to purposefully collaborate, and later given the capacity to use those experiences from the interactions to inform the direction of future developments. In this way, such experiences and information would be channelled towards establishing longterm strategies that could be used to leverage sport tourism, with purposeful collaborations even at the highest levels, and ultimately having a regulatory and institutional framework that governs the development of sport tourism. Such a framework would ensure that sport tourism governance is typified by a non-hierarchical character that stresses shared governance amongst the different stakeholders, including local communities and their service providers for sport tourism events.

Ultimately, clarity and quantification of the interrelationship between sport and tourism would exist, leading to a better understanding of the relationship between the two. Such information could then be used by countries that have similar economies for their sport tourism development initiatives accordingly.

\section{Acknowledgments}

The authors would like to thank the University of Johannesburg for the funding that was made available for the completion of this research. This research contribution presents findings from a PhD research project by the same authors. The authors would also like to thank Prof Kamilla Swart for the useful comments provided to improve the paper.

\section{REFERENCES}

Acha-Anyi, P.N. (2018). Introduction to tourism planning and development: Igniting Africa's tourism economy. Cape Town: Van Schaik Publishers.

Bama, H. \& Tichaawa, T.M. (2015). Major sporting events and responsible tourism: Analysis of the 2013 Africa Cup of Nations (AFCON) tournament in Port Elizabeth, South Africa. African Journal for Physical, Health Education, Recreation and Dance, Supplement 1, 205-219.

Bob, U. \& Swart, K. (2010). Sport events and social legacies. Alternation, 17, (2), 72-95.

Bouhaouala, M. (2015). Definition of sports tourism through a virtuous socio-economic relationship. Proceedings of SENS, Labex Item (1-20), Universite Joseph Fourier, Dijon, France, 12 \& 13 May 2015. Dijon: Jounees Internationales de Management du Sport, du Tourisme Sportif et des Loisirs Actifs.

Bryman, A., Bell, E., Hirschsohn, P., Dos Santos, A., Du Toit, J., Masenge, A., Van Aardt \& Wagner, C. (2014). Research methodology: Business and management contexts. Cape Town: Oxford.

Ciampicacigli, R. \& Maresca, S. (2004). The metalanguages between sport and tourism. Symphonya. Emerging Issues in Management, 1, (2), 73-80. 
Cornelissen, S. (2011). More than a sporting chance? Apprasing the sport for development legacy of the 2010 FIFA World Cup. Third World Quarterly, 32, (3), 503-529.

Fields, A. (2009). Discovering statistics using SPSS. London: SAGE.

Fourie, J. \& Santana-Gallego, M. (2011). The impact of mega-events on tourist arrivals. Tourism Management, 32 (6), 1364-1370.

Gammon, S. \& Robinson, T. (2003). Sport and tourism: A conceptual framework. Journal of Sport Tourism, 8, (1), 21-26.

Getz, D. (2013). Event tourism: Concepts, international case studies and research. Journal of Tourism and Cultural Change, 11 (40, 336-337.

Gibson, H., Kaplanidou, K., \& Kang, S. (2012). Small-scale event sport tourism: a case study in sustainable tourism. Sport Management Review, 15, 160-170.

Gozner, M., Tătar, C.F., Stupariu, M. \& Măduta, F.M. (2017). Nature, Photography and Tourism in Bihor Vlădeasa Mountains (Romania). GeoJournal of Tourism and Geosites, Year X, Volume 20, Oradea-Gdansk.

Harilal, V., Tichaawa, T.M. \& Saarinen, J. (2019). Development without policy: tourism planning and research needs in Cameroon, Central Africa. Tourism Planning and Development, 16(6), 696-705.

Hemmonsbey, J. \& Tichaawa, T. (2018). The effects of major sport event leveraging for tourism and destination branding: The case of South Africa as an emerging destination. GeoJournal of Tourism and Geosites, 21, (1), 213-282.

Hemmonsbey, J. \& Tichaawa, T.M. (2019). Using non-mega events for destination branding: A stakeholder perspective. GeoJournal of Tourism and Geosites, 24, (1), 252-266.

Hermann, U. \& du Plessis, L. (2016). Introduction to tourism and hospitality management: A services approach. Pretoria: Van Schaik Publishers.

Higham, J. \& Hinch, T. (2002). Tourism, sport and seasons: The challenges and potential of overcoming seasonality in the sport and tourism sectors. Tourism Management, 23, 175-185.

Hinch, T. \& Higham, J. (2003). The tourism impacts of Super 12 Rugby in New Zealand. Journal of Sport Management, $17(3), 235-257$.

Honari, H., Goudarzi, M., Heidari, A. \& Emami, A. (2010). A comparison of the viewpoints of tourists, interested managers and cultural heritage organisation managers regarding sport tourism-driven job and income creation in Mazandaran-Iraq. Procedia-Social and Behavioural Science, 2 5659-5663.

Ilieș, D. C., Oneț, A., Marcu, F.M., Gaceu, O.R., Timar, A., Baias, S., Ilieș, A., Herman, G.V. Costea, M., Țepelea, M., Josan, I. \& Wendt, J. (2018a). Investigations regarding the air quality in the historic wooden church in Oradea city, Romania. Environmental Engineering and Management Journal, Vol.17, no11, pp.27312739, http://www.eemj.icpm.tuiasi.ro/pdfs/accepted/204_294_Ilie\%C8\%99_17.pdf.

Ilieș, D. C., Oneț, A., Wendt, J. Ilieș, M., Timar, A., Ilieș, A., Baias, S. \& Herman, G.V. (2018b). Study on microbial and fungal contamination of air and wooden surfaces inside of a istorical Church from Romania. Journal of Environmental Biology, vol 39/6, pp.980-984, http://www.jeb.co.in/ journal_issues/201811_nov18/paper_o6.pdf.

Ilies, D.C., Buhas, R., Ilies, M., Ilies, A., Gaceu, O., Pop, A.C., Marcu, F., Buhas, S.D., Gozner, M., \& Baias, S. (2018c). Sport Activities and Leisure in Nature 2000 Protected Area - Red Valley, Romania. Journal of Environmental Protection and Ecology, 19, No 1, 367-372.

Lincu, A., Ilieș, M., Ilieș, D.C., Herman, G.V., Baias, S., Gozner, M., Costea, M., \& Mihincău, D. (2018). Conservating the traditional cellars of Salacea, Bihor County, Romania. GeoJournal of Tourism and Geosites, 23(3), 748-758, https://doi.org/10.30892/gtg.23311-325.

Jones, I. (2008). Sport fans and spectators as sport tourists. Journal of Sport \& Tourism, 13 (3), 161-164.

Kennelly, M. \& Toohey, K. (2014). Strategic alliances in sport tourism: national sport organisations and sport tour operators. Sport Management Review, 17, 407-418.

Kimbu, A. (2012). Attainment of MDGs through tourism in Central African sub-region: Implications for local economic development in Cameroon. PASOS, 10 (2), 3-16.

Kimbu, A. \& Ngoasong, M. (2013). Centralised decentralisation of tourism development: A network perspective. Annals of Tourism Research, 40, 235-259.

Kimbu A.N. \& Tichaawa, T.M. (2018). Sustainable development goals and socio-economic development through tourism in Central Africa: myth or reality? GeoJournal of Tourism and Geosites, 23(3), 780-796.

Knott, B., \& Hemmonsbey, J. (2015). The strategic value of sport for an African city brand. African Journal of Physical, Health Education, Recreation and Dance, 21 (1), 191-204.

Kurtzman, J. \& Zauhar, J. (2003). A wave in time - the sports tourism phenomena. Journal of Sport Tourism, 8(10, 37-47.

Lamberti, L., Noci, G., Guo, J. \& Zhu, S. (2011). Mega-events as drivers of community participation in developing countries: The case of Shanghai World Expo. Tourism Management, 32 (6), 1474-1483.

Marcu, F., Ilieș, D.C., Wendt, I.A., Indrie, L., Ilieș, A., Burta L., Caciora, T., Herman, G.V., Todoran, A., Baias, S., Albu, A. \& Gozner, M. (2019), Investigations regarding the biodegradation of the cultural heritage. Case study of traditional embroidered peasant shirt (Maramures, Romania). Rom Biotechnol Lett. 2020; 25(2): 1362-1368, doi: 10.25083/rbl/25.2/1362.1368.

Misener, K., Harman, A. \& Doherty, A. (2013). Understanding the local sports I am working very closely with Miss Ngoepe, I have provided majority of feedback, Mr Ntimane, is not truly supporting me here, yet I should indicate that he also had personal problems during the year. I have provided feedback on CHAPTER 1 and 2 - it has been signed off by myself, the student is now working on Chapter 3. Not sure how she will conduct her interviews during the lockdown. She is active and progressing. I also need to mention she received a grant, need to complete her studies this year. council as a mechanism for community sport development. Managing Leisure, 18 (4), 300 - 313. 
Mosedale, J. (2015). Critical engagements with nature: tourism, political economy of nature and political ecology. Tourism Geographies, 17 (4), 505-510.

Nelson, F. (2012). Blessing or curse? The political economy of tourism development in Tanzania. Journal of Sustainable Tourism, 20(3), 359-375.

Ngoka, P.C. \& Umeakuka, O.A. (2013). Sport tourism and sustainable development in Africa. Journal of Research in National Development, 11 (1), 78-89.

Nunkoo, R. (2012). Political economy of tourism: Residents' power, trust in government, and political support for development. Unpublished doctoral thesis. Ontario: University of Waterloo.

Nunkoo, R. \& Smith, S. L. (2013). Political economy of tourism: Trust in government actors, political support, and their determinants. Tourism Management, 36, 120-132.

Nyikana, S. (2016). Using sport tourism events as a catalyst for tourism development in the Eastern Cape Province, South Africa. African Journal of Hospitality, Tourism and Leisure, 5 (3), 1-12.

Nyikana, S., \& Tichaawa, T. (2018a). Sport tourism as a local economic development enhancer for emerging destinations. EuroEconomica, vol. 37, no 2, p. 70-83.

Nyikana, S. \& Tichaawa, T. (2018b). The geography of sport tourists in Cameroon. Proceedings of the Society of South African Geographers (SAAG) Conference, o5 October 2018, University of Free State, QwaQwa Campus: 71-83.

Nyikana, S. \& Tichaawa, T. (2018c). Contextualising sport and tourism in Central Africa: Prospects and challenges. GeoJournal of Tourism and Geosites, 23 (3) 895-909.

Nyikana, S., Tichaawa, T. \& Swart, K. (2014). Sport, tourism and mega-event impacts on host cities: A case study of the 2010 FIFA World Cup in Port Elizabeth. African Journal for Physical, Health Education, Recreation and Dance (AJPHERD), 20 (2), 548-556.

Odounga-Othy, J.D. \& Swart, K. (2016). Sport events as catalysts for tourism and hospitality development in Libreville, Gabon. African Journal of Hospitality, Tourism and Leisure, 5 (3), 1-20.

Pallant, J. (2007). SPSS survival manual. $3^{\text {rd }}$ Edition. New York: McGrath Hill.

Panagiotopoulos, P. (2015). Global sports tourism and the necessity of an institutional framework in Greece. International Sports Law Review Pandektis, 11 (1/2), 416-425.

Radicchi, E. (2013). Tourism and sport: strategic synergies to enhance the sustainable development of a local context. Physical Culture and Sport. Studies and Research, 57, 44-57.

Ramallal, G., Eduardo, M., Rodriguez, M. \& Turegano, S. (2010). Sport and tourism: A potentially conflictual relationship. The case of Marinas in Tenerife. PASOS. Revista de Turismoy Patrimonio Cultural, 8, (2), 265-276.

Rogerson, C. (2013). Tourism and local development in South Africa: Challenging local governments. African Journal for Physical, Health Education, Recreation and Dance (AJPHERD), Supplement 2, 9-23.

Sharma, V. \& Bisht, K. (2019). Carrying capacity assessment and sustainability in Agra City, Uttar Pradesh (India). GeoJournal of Tourism and Geosites, 25, (2,) 399-407.

Smith, A. (2012). Events and urban regeneration: The strategic use of events to revitalise cities. London: Routledge.

Smith, A. \& Stewart, B. (2007). The travelling fan: Understanding the mechanisms of sport fan consumption in a sport tourism setting. Journal of Sport \& Tourism, 12 (3-4), 155-181.

Standeven, J. \& De Knop, P. (1999). Sport tourism. Champaign, IL: Human Kinetics, Champaign, IL.

Swart, K. \& Bob, U. (2007). The eluding link: toward developing a national sport tourism strategy in South Africa beyond 2010. Politikon, 34, (3), 373-391.

Taks, M., Chalip, L., Green, B.C., Kesenne, S. \& Martyn, S. (2009). Factors affecting repeat visitation and flow-on tourism as sources of event strategy sustainability. Journal of Sport \& Tourism, 14, 121-142.

Tichaawa, T. M. \& Swart, K. (2010). Cameroonian fans' perceptions of the 2010 FIFA World Cup: a case study of Buea and Limbe. Alternation, 17 (2), 173-199.

Tichaawa, T.M. (2017). Business tourism in Africa: The case of Cameroon. Tourism Review International, 21, $181-192$.

Tichaawa, T. M. \& Bob, U. (2015). Leveraging mega-events beyond the host nation: a case study of the 2010 FIFA World Cup African Legacy Programme in Cameroon and Nigeria. Leisure Studies, 34(6), 742-757.

Tichaawa, T. M., Bob, U. \& Swart, K. (2018). Africa and sports tourism. In Nauright, J. \& Amara, M. (eds.). Sport in the African world. London: Routledge.

Tichaawa, T.M., Moyo, S., Swart, K. \& Mhlanga, O. (2015). The perceived impacts of sport tourism events: Residents' perceptions in East London, South Africa. African Journal for Physical, Health Education, Recreation and Dance, 21(4:1), 1218-1232.

Tichaawa, T.M. \& Idahosa, L.O. (2020). Adapting Herzberg: redicting attendees' motivation, satisfaction and intention to re- visit a festival in Cameroon using an Ordered Logit Approach. Tourism Review International, DOI: https://doi.org/10.3727/154427220X15845838896323

Uvinha, R.R., Chan, C.S., Man, C.K. \& Marafa, L.M. (2018). Sport tourism: a comparative analysis of residents from Brazil and Hong Kong. Revista Brasileira de Pesquisa Em Turismo, 12 (1), 180-206.

Walker, M., Kaplanidou, K., Gibson, H., Thapa, B., Geldenhuys, S. \& Coetzee, W. (2013). "Win in Africa, with Africa”: Social responsibility, event image, and destination benefits. The case of the 2010 FIFA World Cup in South Africa. Tourism Management, 34, 80-90.

Weed, M. (2003). Why the two won't tango! Explaining the lack of integrated policies for sport and tourism in the UK. Journal of Sport Management, 17 (2), 258-283.

Weed, M. \& Bull, C. (2004). Sports tourism: participants, policy and providers. Oxford: Elsevier ButterworthHeinemann, Oxford.

Submitted:

23.01.2020
Revised:

06.05.2020
Accepted and published online 15.05.2020 